\title{
PENERAPAN SISTEM INFORMASI MANAJEMEN (SIM) DALAM MENDUKUNG PELAYANAN ADMINISTRASI PESERTA DIDIK (Studi Deskriptif di SMA Islam Az Zahrah Palembang)
}

\author{
AQIYLAH RAYHAN, RUSMAINI, AFIF ALFIYANTO \\ Universitas Islam Negeri Raden Fatah Palembang \\ Email : aqiylahrayhan@gmail.com, rusmaini_uin@radenfatah.ac.id, \\ afifalfiyanto_uin@radenfatah.ac.id \\ Article History \\ Received March 27, 2021; Revised June 03, 2021; Accepted June 08, 2021
}

\begin{abstract}
Implementation of Management Information System (SIM) In Supporting Student Administration Service (Descriptive Study at Islamic High School Az Zahrah Palembang)

This research discusses about the implementation of management information systems in supporting the administrative services of students at SMA Islam Az Zahrah Palembang. This study aims to determine how the application of management information systems in supporting the administrative service activities of students at SMA Islam Az-Zahrah. This research uses field research methodology (field research) with data collection techniques in the form of data triangulation by collecting data in the form of observations, interviews, and documentation to obtain the validity of the data obtained with a qualitative descriptive approach. The results of this study indicate that (1) information systems management can help the process of administering students in Az Zahrah Islamic High School which is supported by adequate facilities and infrastructure as well as qualified human resources (2) the supporting factors for the management information system in supporting student administrative services are very adequate school facilities, while the inhibiting factor is the down cycle and Database Maintenance (system update) during the data collection process. The implication of this research is that education personnel are expected to always update the latest information on the school's official Wabside. Because after being reviewed, so far there are still many students who do not know about the existence of an official school wabside and schools should provide a special room for school administrative management, in order to improve the performance of school operators.
\end{abstract}

Keywords: Information Systems, Management Information Systems, Student Administration Services

Abstrak: Penerapan Sistem Informasi Manajemen (SIM) dalam Mendukung Pelayanan Administrasi Peserta Didik (Studi Deskriptif di SMA Islam Az Zahra Palembang)

membahas pentang penerapan sistem informasi manajemen dalam mendukung pelayanan administrasi peserta didik di SMA Islam Az Zahrah palembang. Penelitian ini bertujuan untuk mengetahui bagaimana penerapan sistem informasi manajemen dalam mendukung aktivitas pelayanan administrasi peserta didik yang ada di SMA Islam Az-Zahrah. Penelitian ini menggunakan metode penelitian field reseacrh (penelitian lapangan) dengan 
teknik pengumpulan data berupa trianggulasi data dengan cara pengumpulan data berupa observasi, wawancara, dan dokumentasi untuk mendapatkan keabsahan data yang diperoleh dengan pendekatan deskriptif kualitatif. Hasil dari penelitian ini menunjukkan bahwa (1) sistem informasi manajemen dapat membantu jalannya proses pengadministrasian peserta didik yang ada di SMA Islam Az Zahrah yang didukung dengan sarana dan prasarana yang memadai serta tenaga SDM yang berkualitas (2) faktor pendukung sistem informasi manajemen dalam mendukung pelayanan administrasi peserta didik adalah fasilitas sekolah yang sangat memadai, sedangkan faktor penghambaynya adalah siklus down dan maintenance database (pembaharuan sistem) saat proses pendataan. Implikasi pada penelitian kali ini adalah tenaga kependidikan diharapkan untuk selalu mengunggah informasi terbaru di Wabside resmi sekolah. Karena setelah ditinjau, sejauh ini masih banyak peserta didik yang belum mengetahui adanya wabside resmi sekolah dan hendaknya sekolah menyediakan ruangan khusus untuk pengelolaan tata usaha sekolah, agar dapat meningkatkan kinerja operator sekolah.

Kata Kunci : Sistem Informasi Manajemen, Pelayanan Administrasi Peserta Didik

\section{PENDAHULUAN}

ebutuhan informasi saat ini semakin hari semakin mendesak sejalan dengan arus globalisasi yang terjadi di seluruh belahan dunia. Implementasi sistem

informasi manajemen yang berbasis kompetisi menjadi kebutuhan yang mutlak dan dapat memberikan keunggulan kompetitif sehingga menjadi prioritas yang tinggi. Sejalan dengan perkembangan ilmu pengetahuan dan teknologi, semakin pesat pula tuntutan dalam memberikan informasi yang cepat, tepat, dan akurat pada berbagai macam instansi salah satunya ialah pada lembaga pendidikan yang seharusnya menerapkan sistem komputerisasi sebagai sarana utama dalam menangani kendala-kendala dalam pendataan (Zakia, 2019) .

Lembaga pendidikan dituntut untuk mampu mengembangkan sistem informasi guna meningkatkan layanan pendidikan. Diantara kebutuhan tersebut adalah penyediaan akses data dan informasi yang diperoleh dari proses menghimpun, mendata, mengolah, mengadakan, menyimpan, dan mengirim sampai informasi tersebut diterima oleh pembuat keputusan ujar (Hisbanatro, Vico, 2014). Kemajuan ilmu yang semakin hari semakin pesat banyak mengubah sudut pandang dan gaya hidup masyarakat termasuk pada dunia pendidikan. Peningkatan kerja pendidikan dimasa mendatang memerlukan sistem informasi yang mendukung keberhasilan sebuah lembaga sehingga mampu bersaing pada pasar global (Ismail dan Sinen, 2017). Zakia (2019, h. 58) mengungkapkan bahwa "Implementasi sistem informasi manajemen sangat dibutuhkan dalam kemajuan suatu lembaga untuk dapat bersaing sampai memperoleh preferensi yang baik". Dilihat dari definisinya sistem informasi manajemen merupakan sebuah sistem yang bertugas untuk menyalurkan support berupa informasi untuk peran tata laksana serta metode pencapaian hasil. 
Seperti yang dikutip Hasanah (2020, h. 15), "Sistem informasi manajemen merupakan bagian dari ilmu manajemen". Semua fungsi manajemen baik itu perencanaan, pengorganisasian, kepemimpinan, dan pengendalian diperlukan untuk keberhasilan sebuah organisasi terutama dalam bidang pendidikan. Manajemen yang baik dalam suatu lembaga pendidikan pendidikan akan menjadi hal yang mutlak bagi keberlangsungan hidup suatu lembaga tersebut. Adapun salah satu hal yang penting dalam mengembangkan suatu lembaga pendidikan adalah pengelolaan sistem informasi yang baik dan tepat.

Menurut Rocheaety, Rahayuningsih, dan Yani (2009) mengungkapkan bahwa diterapkannya sistem informasi manajemen pada sebuah lembaga pendidikan,. berfungsi sebagai pendukung kegiatan manajemen mulai dari planning (perencanaan), organizing (pengorganisasian), staffing (kepegawaian), directing (pengarahan), coordinating (pengkoordinasian), evaluating (evaluasi), dan budgeting (penganggaran) dalam rangka menunjang tercapainya sasaran dan tujuan serta fungsi-fungsi operasional dalam suatu lembaga pendidikan (Handoko, 2012). berpendapat bahwa sistem informasi merupakan salah satu komponen yang. tidak dapat dipisahkan satu dengan yang lainnya dari aktivitas pendidikan itu sendiri. Kedua domain ini memiliki tingkat ketergantungan yang cukup tinggi dalam membentuk karakteristik dunia pendidikan. Kedua aspek tersebut menggambarkan pendidikan sebagai penggerak (drive) terhadap sistem informasi pendidikan, sedangkan informasi pendidikan akan menjadi penentu kinerja pendidikan. Di sisi lain pengembangan sistem informasi manajemen pada lembaga pendidikan sangatlah dibutuhkan, karena dalam menghadapi persaingan global lembaga pendidikan dituntut untuk memberikan informasi lebih cepat, akurat dan nyaman yang merupakan bagian dari kualitas pelayanan, .sehingga akan menjadi sebuah keunggulan dalam bersaing (competitive advantage) (Rocheaety, Rahayuningsih, dan Yani, 2009).

Sallis (2006, h. 6) mengatakan bahwa "Suatu lembaga pendidikan dapat mencapai competitive advantage (keunggulan bersaing) apabila lembaga tersebut dapat memberikan jasa ataupun pelayanan yang sesuai dengan kebutuhan pelanggan, sehingga pelanggan menjadi puas dengan layanan yang diberikan". Pemanfaatan sistem informasi manajemen dalam bidang pendidikan biasanya disebut dengan SIMDIK (Sistem Informasi Manajemen Pendidikan) yang sangat diperlukan dalam pengelolaan atau layanan pendidikan, yaitu antara lain dalam pelayanan pengajaran, administrasi, fasilitas sekolah, maupun pelayanan peserta didik (Sonia, 2020). Di samping itu dalam menghadapi era globalisasi, semakin hari sistem informasi semakin dibutuhkan oleh lembaga pendidikan khususnya dalam meningkatkan kelancaran informasi dalam lembaga pendidikan, kontrol kualitas, dan menciptakan kerjasama dengan pihak lain yang dapat meningkatkan nilai lembaga pendidikan tersebut. 
Proses pengadministrasian peserta didik yang ada di SMA Islam Az Zahrah dilakukan dengan 2 cara, baik secara tersistem ataupun secara manual. Di sisi lain penerapan sistem informasi manajemen juga merupakan suatu hal terpenting dalam sebuah lembaga pendidikan juga sebagai tantangan untuk menyediakan informasi yang cepat, tepat, akurat, tanpa ada hambatan. Di samping itu seperti yang dikatakan (Yakub, 2014) bahwasanya lembaga pendidikan juga dituntut untuk mampu mengembangkan sistem informasi guna meningkatkan layanan pendidikan termasuk dalam pelayanan administrasi peserta didik di sekolah. Dengan adanya pemenuhan fasilitas dan sarana yang ada, maka sudah seharusnya dan sudah semestinya setiap lembaga pendidikan sudah menerapkannya dengan baik terkhusus dalam proses pelayanan pengadministrasian peserta didik.

Tujuan penelitian ini adalah mengetahui bagaimana sekolah menerapkan sistem informasi manajemen dalam pelaksanaan pengadministrasian peserta didiknya dan mengetahui apa saja faktor pendukung dan penghambat dalam penerapan sistem informasi manajemen dalam mendukung pelayanan administrasi peserta didik. Berdasarkan uraian di atas, penulis tertarik untuk meneliti lebih dalam tentang penerapan sistem informasi manajemen dalam mendukung pelayanan administrasi peserta didik yang ada di SMA Islam Az Zahrah Palembang.

\section{METODE PENELITIAN}

Jenis penelitian ini menggunakan metode kualitatif deskriptif yang dimana peneliti menggunakan teknik field reseach (penelitian lapangan). Penelitian lapangan adalah penelitian yang dilakukan dengan menggunakan informasi yang diperoleh penulis di tempat penelitian. Subjek dalam penelitian adalah operator sekolah, sedangkan informan pendukung penelitian yaitu kepala sekolah, wakil kepala sekolah bidang sarana dan prasarana, tenaga pendidik dan tenaga kependidikan serta peserta didik. Data dikumpulkan dalam bentuk observasi, dokumentasi dan wawancara. Kemudian hasilnya dianalisis dengan menggunakan teknik analisis data yang berupa pengumpulan data, reduksi data, penyajian data dan penarikan kesimpulan.

\section{HASIL DAN PEMBAHASAN}

Jika dipersentasekan dari hasil penelitian, penerapan sistem informasi manajemen dalam mendukung pelayanan administrasi peserta didik yang ada di lapangan penerapannya sudah dilakukan sekitar 85\%. Dibuktikan berdasarkan hasil observasi langsung yang dilakukan penulis melalui metode wawancara dan dokumentasi. Diperjelas dengan Yakub (2014) bahwasanya setiap lembaga pendidikan dituntut untuk mampu mengembangkan sistem informasi guna meningkatkan layanan pendidikan yang diantara kebutuhan tersebut adalah penyediaan akses data dan informasi yang diperoleh dari proses menghimpun, mendata, mengolah, pemrograman data, hingga penyimpanan data. Maka dari itu, 
jelas dapat dikatakan bahwasanya penerapan sistem informasi manajemen dalam mendukung pelayanan administrasi peserta didik sangatlah penting dalam lembaga pendidikan.

SMA Islam Az Zahrah Palembang menggunakan Dapodik sebagai alat pendukung pengadministrasian peserta didik, yang dimana Dapodik adalah Aplikasi pengelolaan data sekolah dan dinaungi langsung oleh kementrian pendidikan dan kebudayaan. Proses pengadministrasian peserta didik melalui Dapodik itu sendiri, dilakukan mulai dari pendataan peserta didik dan orang tua secara lengkap, tenaga pendidik dan tenaga kependidikan, mutasi siswa, rombongan belajar, mata pelajaran, siswa berprestasi, nilai ujian dan nilai rapor siswa, serta pendataan siswa yang mendapatkan Kartu Indonesia Pintar. Di samping itu dengan dukungan sarana dan prasarana yang menunjang jalannya penerapan SIM, SMA Islam Az Zahrah dapat memberikan layanan pendidikan yang baik dengan memanfaatkan teknologi dan fasilitas yang telah disediakan.

\section{Aplikasi Pengolahan Data Sekolah (Dapodik)}

Berdasarkan hasil wawancara bersama operator sekolah, yang dikutip sebagai berikut:

“Dari 100\% penerapan sistem informasi manajemen dalam pelayanan administrasi peserta didik yang ada di sekolah ini sudah dilaksanakan 85\%. Untuk 15\%-nya belum sepenuhnya terlaksana karena sering terjadi hambatan dalam proses pengadministrasian peserta didik melalui Dapodik, diantaranya hambatan yang sering terjadi adalah siklus down saat koneksi internet buruk dan menghambat proses pendataan, sinkronisasi dalam validasi data peserta didik, hingga maintenance database (pembaharuan dan pemeliharaan sistem) yang dilakukan pemerintah pusat dengan jangka waktu yang tak bisa ditentukan." Ujar Rizka Tri Wardani.

\section{Penerapan Sistem Informasi Manajemen di SMA Islam Az Zahrah Palembang}

Penerapan Sistem Informasi Manajemen di SMA Islam Az Zahrah Palembang dapat dilihat dari :

Kepala SMA Islam Az Zahrah yang berperan sebagai top leader yang mempunyai peran utama, dimana ia juga memberikan pelayanan kepada para peserta didik dalam hal pemanfaatan teknologi informasi melalui penggunaan Wi-Fi atau jaringan internet. SMA Islam Az Zahrah menyediakan akses informasi mengenai status sekolah sebagai nilai tambah sekolah kepada masyarakat yang bisa diakses di https://az-zahrah.net/.

SMA Islam Az Zahra menggunakan satu perangkat lunak berbasiskan aplikasi resmi di bawah naungan Kementerian Pendidikan dan Kebudayaan yang dimaksudkan untuk menunjang kegiatan-kegiatan sekolah dengan tujuan menyediakan layanan informasi bagi sekolah, kepala sekolah, tenaga pendidik, tenaga kependidikan, maupun stakeholder sekolah yang membutuhkan, serta 
memberi nilai tambah bagi profil sekolah, sehingga bisa meningkatkan daya saing yang lebih baik.

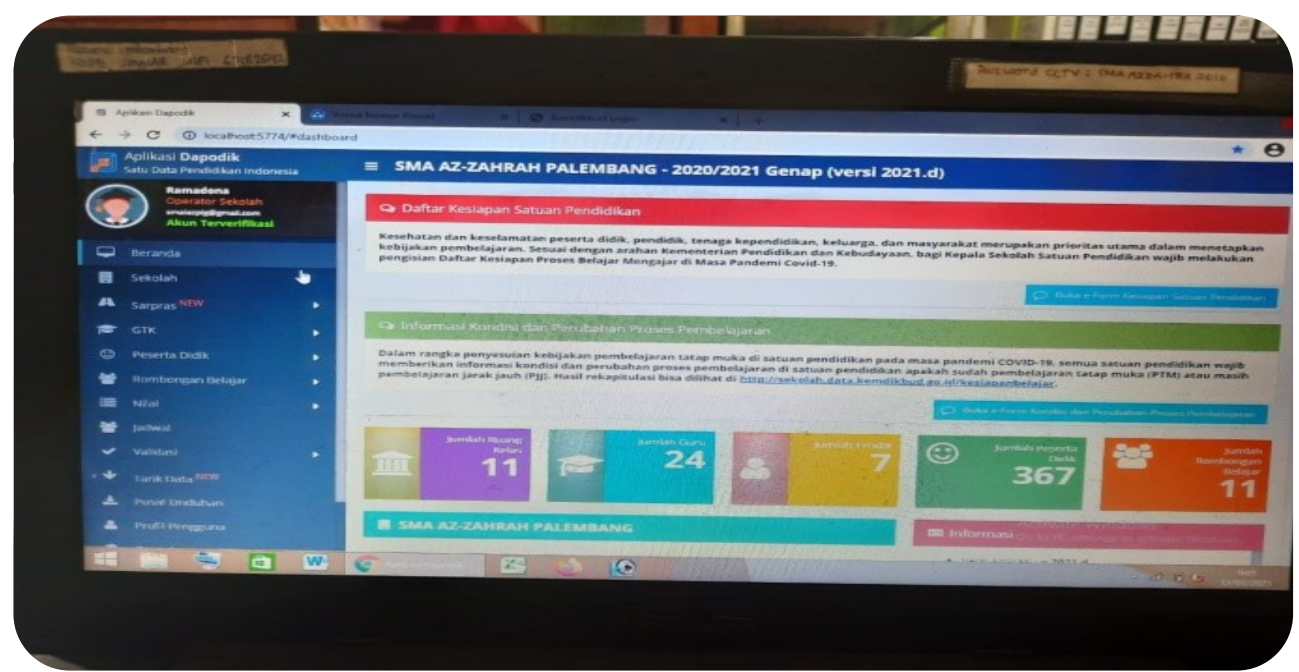

Gambar 1. Aplikasi Dapodik SMA Islam Az Zahrah

\section{Pelayanan Administrasi Peserta didik}

Demi kelancaran kegiatan, sistem informasi manajemen mempunyai bagianbagian yang bertugas untuk mengkoordinir semua bagian dan bertanggung jawab langsung pada kepala sekolah, meliputi bagian pengumpulan data, penginputan data, dan penyimpanan data. Semua kegiatan dikerjakan oleh pihak tenaga kependidikan (Tata Usaha) khususnya operator sekolah. Dapat dikatakan kegiatan pelayanan administrasi peserta didik adalah kegiatan yang dimulai ketika peserta didik masuk hingga peserta didik tersebut menyelesaikan pendidikannya di sekolah tersebut baik lulus maupun pindah ke sekolah lainnya.

\section{Bagian Pengumpulan Data}

Pengumpulan data dilakukan secara internal maupun eksternal. Data internal merupakan data yang berasal dari dalam sekolah itu sendiri, sedangkan data eksternal merupakan data yang berasal dari luar lembaga pendidikan tetapi masih terdapat hubungan dengan perkembangan suatu lembaga pendidikan tersebut. Pada dasarnya data diperoleh dari fakta-fakta yang ada di lapangan. Fakta yang dijadikan data adalah fakta yang memiliki nilai tertentu sesuai dengan kebutuhan lembaga pendidikan (sekolah) dan akan menjadi informasi. Pengumpulan data dapat berjalan dengan baik dan normal apabila semua komponen sekolah atau seluruh bagian yang terkait menyerahkan data tepat waktu dan saling bekerja sama untuk mencapai tujuan organisasi.

\section{Bagian Pengolaan Data}

Program perencanaan pendidikan nasional merupakan bagian terpenting dalam mewujudkan rencana strategis pembangunan pendidikan nasional, 
diantaranya peningkatan akses, mutu, serta tata kelola pendidikan nasional. Untuk membangun program perencanaan pendidikan yang terstruktur dan berkesinambungan diperlukan data-data pendukung yang lengkap dan valid. Berdasarkan kebutuhan tersebut, program perencanaan pendidikan membangun sistem pendataan terbaru yang dimana proses pendataannya dilakukan secara terpusat, online, dan real time dengan menggunakan aplikasi Dapodik.

Dapodik adalah suatu sistem pendaaan dan pengelolaan data-data pendidikan yang bersifat micro secara online. Terdapat jenis data utama pendidikan yang dikelola pada sistem Dapodik, meliputi data sekolah, data peserta didik, data tenaga pendidik serta data tenaga kependidikan. Dapodik bertujuan untuk mewujudkan basis data, sehingga dapat tercipta tata kelola pendidikan yang terpadu dan menghasilkan data maupun informasi yang representatif untuk memenuhi kebutuhan kementrian dan pemangku kepentingan lainnya serta untuk mendukung peningkatan efesiensi, efektivitas, dan sinergi dalam kegiatan pengumpulan data pokok yang terintegrasi dalam satu sistem pendataan. Selain menggunakan Dapodik pengadministrasian peserta didik juga dilakukan secara manual sebagai data pembukuan sekolah yang berbentuk hard copy. Instrumen yang tercantum didalamnya antara lain :

\section{Buku Induk}

Dalam buku induk ini termuat semua data peserta didik mulai dari data diri peserta didik, riwayat pendidikan, data orang tua, nilai rapor serta nilai ujian.

\section{Buku Klapper}

Format buku klapper yang ada di SMA Islam Az Zahrah seperti yang tertera dibawah ini :

Tabel 1. Format Buku Klapper

\begin{tabular}{|c|c|c|c|c|c|c|c|c|c|}
\hline \multirow{3}{*}{ No } & \multirow{3}{*}{ Nama Siwa } & \multirow{3}{*}{ JK } & \multirow{3}{*}{$\begin{array}{c}\text { Nama } \\
\text { Orang } \\
\text { Tua }\end{array}$} & \multirow{3}{*}{ No.I } & \multicolumn{4}{|c|}{ Waktu } & \multirow{3}{*}{ Ket } \\
\hline & & & & & \multicolumn{2}{|l|}{ Masuk } & \multicolumn{2}{|l|}{ Keluar } & \\
\hline & & & & & Tg| & $\mathrm{KI}$ & Tgl & $\mathrm{KI}$ & \\
\hline 1 & Abmiriansyah & $\mathrm{L}$ & Abdul & 1378 & $14 / 07 / 14$ & $\mathrm{X}$ & $02 / 05 / 17$ & XII & $\mathrm{L}$ \\
\hline 2 & Achmad Sayyid & L & Murdijaya & 1379 & $15 / 07 / 14$ & $X$ & $03 / 05 / 17$ & XII & L \\
\hline 3 & Adelia Nurimani & $P$ & Kasyiron & 1380 & $16 / 07 / 14$ & $X$ & $04 / 05 / 17$ & XII & $\mathrm{L}$ \\
\hline
\end{tabular}

Sumber: Observasi langsung di SMA Islam Az Zahrah (Data Tahun 2017)

\section{Buku Mutasi (Perpindahan Siswa)}

Format buku ini digunakan untuk mencatat data peserta didik yang baru pindah dari sekolah lain ataupun peserta didik yang semula bersekolah di SMA Islam Az Zahrah pindah ke sekolah lain.

Tabel 2. Format Buku Mutasi (Masuk)

\begin{tabular}{|c|c|c|c|c|}
\hline \multicolumn{5}{|c|}{ Murid yang Masuk } \\
\hline Tgl & Nama & L/P & Kelas & No.D.I \\
\hline- & - & - & - & - \\
\hline
\end{tabular}

Sumber: Observasi Langsung di SMA Islam Az Zahrah (Data Tahun 2021) 
Tabel 3. Format Buku Mutasi (Keluar)

\begin{tabular}{|c|l|l|l|l|}
\hline \multicolumn{5}{|c|}{ Murid yang keluar } \\
\hline Tgl & \multicolumn{1}{|c|}{ Nama } & L/P & Kelas & No.D.I \\
\hline $01 / 02 / 2021$ & Alif Akbar hamdallah & L & X.Ips & \\
\hline
\end{tabular}

Sumber: Observasi Langsung di SMA Islam Az Zahrah (Data Tahun 2021)

\section{Buku Daftar Kehadiran Peserta Didik}

Tercatat dalam pendataan, peserta didik yang bersekolah di SMA Islam Az Zahrah Tahun ajaran 2020/2021 sebanyak 369 siswa.

Tabel 4. Format Buku Kehadiran Peserta Didik

\begin{tabular}{|c|c|c|c|c|c|}
\hline \multirow{2}{*}{ No } & \multirow{2}{*}{ Kelas } & \multicolumn{3}{|c|}{ Jumlah } & \multirow{2}{*}{ Ket } \\
\cline { 3 - 5 } & & LK & PR & Total & 4 Kelas \\
\hline 1 & $\mathrm{X}$ & 65 & 68 & 133 & 3 Kelas \\
\hline 2 & $\mathrm{XI}$ & 51 & 57 & 108 & 4 Kelas \\
\hline 3 & $\mathrm{XII}$ & 72 & 55 & 127 & \\
\hline \multicolumn{2}{|c|}{ Jumlah } & & & 369 & \\
\hline
\end{tabular}

Sumber: Observasi Langsung di SMA Islam Az Zahrah (Data Tahun 2020)

\section{Daftar Hadir Peserta Didik}

Seperti yang diungkapkan oleh Hidayati

“Jikalau seperti pandemi seperti saat ini, pembelajaran dilakukan secara daring, maka daftar hadri peserta didik dikumpulkan oleh setiap guru mata pelajaran, kemudian proses pembelajaran melalui aplikasi Zoom dan Google Classroom. Seperti hari karena sedang melaksanan proses ujian mid semester, jadi operator ujiannya membagikan dua tugas di Google Classroom untuk siswa absen dan satu tugas yang berisi link Google Form untuk ujian dilaksanakan."

\section{Bagian Penyimpanan Data}

Bagian penyimpanan data bertugas untuk menyimpan data ataupun yang berkaitan dengan arsip sekolah, sehingga memudahkan pencarian dan pengambilan data mentah ataupun yang sudah diolah saat data itu diperlukan. Maka dari itu dapat disimpulkan bahwasanya pemanfaatan teknologi informasi sebagai alat penyimpanan data sangatlah diperlukan karena bertujuan untuk menjaga keamanan data dan meminimalisir biaya penyimpanan. Di samping itu penyimpanan informasi juga sangatlah penting karena tidak semua informasi yang dimiliki digunakan saat sekarang namun saat dibutuhkan.

Faktor pendukung dan Faktor Penghambat Penerapan Sistem Infromasi Manajemen dalam Mendukung Aktivitas Pelayanan Administrasi Peserta Didik

Faktor pendukung penerapan sistem infromasi manajemen dalam mendukung aktivitas pelayanan administrasi peserta didik diantaranya, yaitu: 
1. Adanya sumber daya manusia (SDM) yang memadai baik secara kualitas maupun kuantitas. Hal ini juga didukung oleh kemauan tenaga kependidikan yang terus aktif mengikuti perkembangan zaman.

2. Pemenuhan kebutuhan sarana dan prasarana yang diperlukan operator sekolah dalam menjalankan tugasnya. Seperti penyediaan komputer dan laptop.

3. Adanya jaringan koneksi internet ataupun Wi-Fi yang lancar, dan kenyamanan ruangan untuk bekerja, sehingga mempermudah para tenaga kependidikan untuk melaksanakan tugasnya.

4. Tersedianya aplikasi pendukung untuk melakukan pendataan baik peserta didik, tenaga pendidik maupun tenaga kependidikan melalui aplikasi Dapodik.

5. Adanya kerjasama dari berbagai pihak baik kepala sekolah, wakil kepala sekolah bagian sarana dan prasarana, wakil kepala sekolah bidang kesiswaan, wakil kepala sekolah bagian kurikulum (pembelajaran), serta para tenaga pendidik dan tenaga kependidikan dalam hal pengadministrasian peserta didik.

Faktor penghambat penerapan sistem infromasi manajemen dalam mendukung aktivitas pelayanan administrasi peserta didik bersumber dari hambatan eksternal dan hambatan internal. Hambatan internal terjadi dari dalam lingkup sekolah itu sendiri, contohnya :

1. Keterlambatan peserta didik ataupun objek pengumpulan data menyerahkan data yang telah disatukan keoperator sekolah.

2. Terjadinya siklus down saat penginputan data dikarenakan jaringan yang kurang stabil.

3. Terjadinya pemadaman lampu saat pengunggahan data, sehingga data yang sudah diupload belum terpastikan sudah terdata ataupun belum

4. Terjadinya in valid dalam pendataan rombongan belajar ataupun jadwal pelajaran, sehingga pihak operator sekolah harus melihat data sebelumnya.

Sedangkan faktor eksternal berasal dari lingkungan sekolah itu sendiri. Baik dari dinas pendidikan pusat ataupun dinas pendidikan provinsi ataupun dinas pendidikan kota. Contohnya seperti sering terjadinya maintenance database (pembaharuan sistem) yang lama, hingga bisa memakan waktu hingga 2 minggu bahkan lebih dengan waktu yang tidak dapat ditentukan, sehingga operator sekolah tidak bisa mengakses data pembaharuan ke Dapodik dan harus menunggu maintenance database selesai barulah bisa mengakses Dapodik kembali.

\section{PENUTUP/SIMPULAN}

Berdasarkan analisa hasil penelitian yang telah dikemukakan pada pembahasan sebelumnya, peneliti menarik kesimpulan bahwa SMA Islam Az Zahrah sudah cukup baik dalam menerapkan sistem informasi manajemen dalam mendukung pelayanan administrasi peserta didik, maka dari itu dapat ditarik kesimpulan bahwa penerapan sistem informasi manajemen dalam mendukung pelayanan administrasi peserta didik sangatlah penting dalam lembaga pendidikan 
untuk memperoleh competitive advantage (keunggulan bersaing) dengan lembaga pendidikan lain. SMA Islam Az Zahrah Palembang menggunakan Dapodik sebagai alat pendukung pengadministrasian peserta didik yang langsung disupervisi oleh kementerian pendidikan dan kebudayaan pusat. Dapodik berisikan tentang data lengkap peserta didik itu sendiri, orang tua, pendataan tenaga pendidik dan tenaga kependidikan, pendataan mutasi siswa, rombongan belajar, mata pelajaran, siswa berprestasi, serta pendataan siswa yang mendapatkan Kartu Indonesia Pintar. Di samping itu dengan dukungan sarana dan prasarana yang menunjang jalannya penerapan SIM seperti penyediaan akses internet (Wi-Fi) yang stabil, SMA Islam Az Zahrah dapat memberikan layanan pendidikan yang baik dengan memanfaatkan teknologi dan fasilitas yang telah disediakan.

Faktor pendukung penerapan sistem informasi manajemen dalam pelayanan administrasi peserta didik di SMA Islam Az Zahrah adalah (1) sarana dan prasaran yang bisa dikatakan sudah lebih dari cukup untuk melakukan proses pengadminstrasian terutama dalam proses administrasi peserta didik, (2) ketersedian SDM yang berkualitas untuk mengelola tata usaha sekolah, (3) kerjasama yang baik antar steakholder sekolah. Sedangkan faktor penghambat yang mempengaruhi proses pengadministrasian peserta didik secara online adalah (1) terjadinya siklus down saat pengunggahan data, (2) maintenance database (pembaharuan ataupun pemeliharaan sistem) yang tidak tentu waktu dan tanggal pelaksanaannya karena diperbarui oleh dinas pendidikan terpusat, (3) keterbatasan ruangan tata usaha sekolah yang masih bercampur dengan ruangan lain, sehingga terlihat sempit dan mengganggu keefektifan kinerja tenaga kependidikan maupun operator sekolah.

\section{DAFTAR PUSTAKA}

Handoko, T. Hani. (2012). Manajemen. Yogyakarta: BPFE Yogyakarta.

Hasanah, Mizanul. (2020). Sistem Informasi Manajemen Pendidikan Keluarga Dalam Islam Berdasarkan Al Quran dan Al Hadist. Jurnal Manajemen $\begin{array}{llll}\text { Pendidikan } & \text { Islam, } & \text { 3(1). } & \text { 14-28. }\end{array}$ DOI: http://dx.doi.org/10.30868/im.v3i01.629

Hisbanatro, Vico, Y. (2014). Sistem Informasi Manajemen Pendidikan. Yogyakarta: Graha IImu. p.31

Ismail, La Ode. dan Sinen, Ristati. (2017). Penerapan Sistem Informasi Manajemen Pendidikan dalam Proses Pembelajaran di SMP Negeri 21 Makassar. Jurnal Idaarah: Manajemen Pendidikan, 1(2). pp. 290-309. DOI: https://doi.org/10.24252/idaarah.v1i2.4272

Rocheaety, Eti. Rahayuningsih, Pontjorini. dan. Yani, Prima Gusti. (2009). Sistem Informasi Manajemen Pendidikan. PT Bumi Aksara. p.14-15

Sallis, Edward. (2006). Total Quality Manajemen. Yogyakarta: IRC Icod.p. 6 
Sonia, Nur Rahmi. (2020). Implementasi Sitem Informasi Manajemen Pendidikan (SIMDIK) dalam Meningkatkan Mutu Pendidikan di MAN 2 Ponogoro. Southeast Asian Journal Of Islamic Education Manajemen, 1(1). pp. 94-104. DOI: https://doi.org/10.21154/sajiem.v1i1.18

Yakub. (2014). Pengantar Sistem Informasi. Tegal: Grass Media. p. 23.

Zakia, Hanifa. (2019). Pemanfaatan Sistem Informasi Manajemen sebagai Strategi dalam Menjalin Kerjasama Sekolah dengan Wali Murid di Sekolah Menengah Pertama Negeri 1 Talamu. Jurnal Bahana Manajemen Pendidikan, 8(1).pp. 58-65. DOI : https://doi.org/10.24036/bmp.v8i1.105301 